\title{
Investigation of important biochemical compounds from selected freshwater macroalgae and their role in agriculture
}

Zahir Shah', Syed Lal Badshah ${ }^{2 *}$, Arshad lqball ${ }^{*}$, Zamarud Shah $^{3}$, Abdul-Hamid Emwas $^{4}$ and Mariusz Jaremko ${ }^{5^{*}}$

\begin{abstract}
Background: Freshwater macroalgae possess a number of important secondary metabolites. They are an unexplored source of medicinal compounds. In this study, three freshwater macroalgae-Chara vulgaris, Cladophora glomerata and Spirogyra crassa - were collected from the river Swat and the river Kabul in the Charsadda district of Khyber Pakhtunkhwa, Pakistan. To assess the role of freshwater macroalgae in agriculture, various experiments were performed on their extracts. Methanolic extract of the three macroalgae were first analyzed through gas chromatography-mass spectrometry (GC-MS) for the presence of important medicinal secondary metabolites. The methanol based macroalgae extracts were tested for antibacterial, insecticidal, cytotoxic and phytotoxic activities.
\end{abstract}

Results: Initially, the algae were dried, crushed and treated with methanol for the extraction of secondary metabolites. The GC-MS results contained several important long chain fatty acids and other related long-chain hydrocarbons, such as alkanes and alkenes. Several benzene derivatives were also detected during the course of the investigation. Several of these compounds have established roles in the treatment of human ailments and can be supplied to farm animals. For example, phenylephrine is a decongestant, dilates pupils, increases blood pressure and helps in relieving hemorrhoids. Hexahydropseudoionone has uses in perfumes and other cosmetics. Several essential oils were also detected in the methanolic extract of the three macroalgae that can be utilized in various industrial products. Bioassays showed that these algal extracts—especially the Spirogyra sp. extract—contain moderate to maximum bioactivity.

Conclusions: Macroalgae possess important secondary metabolites with medicinal properties. These secondary metabolites can be used as biopesticides, plant growth enhancers, and remedies for various diseases in farm animals and for the control of weeds. They can be further explored for isolation and purification of useful biochemical compounds.

Keywords: Essential oils, Macroalgae, Gas chromatography, Mass spectrometry, Fatty acids, Bioassays

\footnotetext{
*Correspondence: shahbiochemist@gmail.com; arshad.iqbal@icp.edu.pk;

Mariusz.jaremko@kaust.edu.sa

1 Department of Botany, Islamia College University Peshawar,

Peshawar 25120, Pakistan

2 Department of Chemistry, Islamia College University Peshawar,

Peshawar 25120, Pakistan

${ }^{5}$ Division of Biological and Environmental Sciences and Engineering

(BESE), King Abdullah University of Science and Technology (KAUST),

Thuwal 23955-6900, Saudi Arabia

Full list of author information is available at the end of the article
}

\section{Springer Open}

(c) The Author(s) 2022. Open Access This article is licensed under a Creative Commons Attribution 4.0 International License, which permits use, sharing, adaptation, distribution and reproduction in any medium or format, as long as you give appropriate credit to the original author(s) and the source, provide a link to the Creative Commons licence, and indicate if changes were made. The images or other third party material in this article are included in the article's Creative Commons licence, unless indicated otherwise in a credit line to the material. If material is not included in the article's Creative Commons licence and your intended use is not permitted by statutory regulation or exceeds the permitted use, you will need to obtain permission directly from the copyright holder. To view a copy of this licence, visit http://creativecommons.org/licenses/by/4.0/. The Creative Commons Public Domain Dedication waiver (http://creativeco mmons.org/publicdomain/zero/1.0/) applies to the data made available in this article, unless otherwise stated in a credit line to the data. 


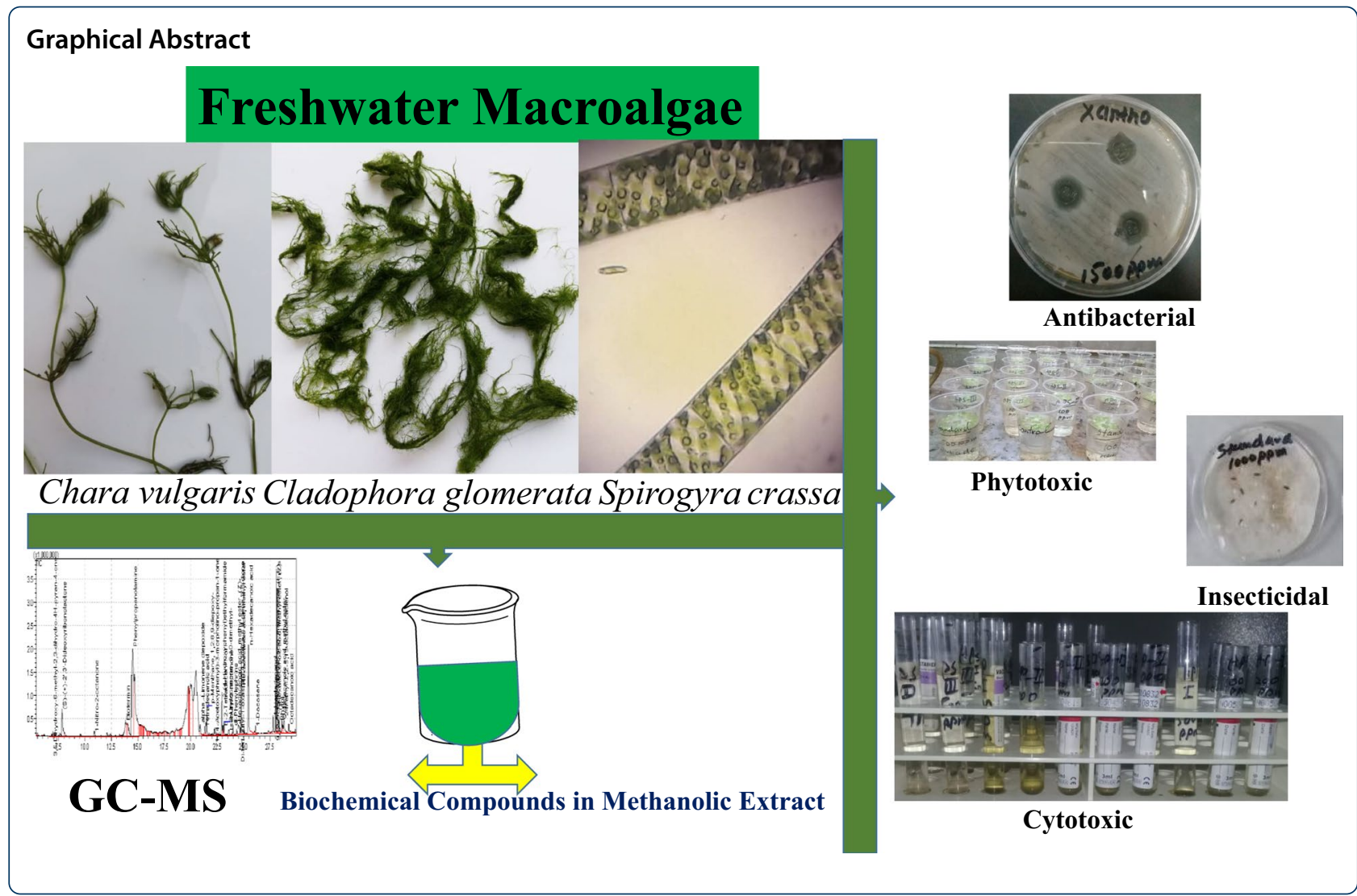

\section{Introduction}

Algae are a heterogeneous group of plant-like organisms that belongs to the kingdom Protista. They are comprised of the dominant photoautotrophs, from simple microscopic or macroscopic to multicellular plants, present in diverse aquatic habitats from freshwater bodies to vast marine water [1]. Actively growing algae convert the sun's energy into a diverse group of metabolites called bioactive compounds. These bioactive substances include carbohydrates, proteins, lipids, phenols, vitamins, free amino acids, enzymes and growth regulators [2]. Phycologists have investigated various forms of natural bioactive compounds present in marine algae from all over the world. A number of fatty acids (both saturated and unsaturated), terpenes, sterols and carbohydrates have been extracted from different algae. In contrast to comprehensive data available on marine algae, phytochemical information for freshwater macroalgae is incomplete [3]. Members of the Chlorophyceae class of green algae are a source of bioactive compounds with diverse chemical structures and biological activities, with an approximately 3.98 billion dollar market in 2018 [4]. Both marine and freshwater algae are a good source of pharmacologically active metabolites $[5,6]$. The presence of bioactive secondary metabolites with antitumor activity [6], antibacterial [7], antioxidant [8], and anti-inflammatory [8] activities has been recognized in various macroalgae as they contain active biological phytochemicals, such as fatty acids, sterols, peptides, proteins, polysaccharides, heterocyclic carbons and terpenes [9]. Cladophora, for example, has more than 183 species and all have diverse phytochemicals with medicinal properties [10].

Algal products can be used for sustainable agriculture; to increase plant growth and soil nutrients, control soil toxicity, and as bio-fertilizers and bio-pesticides [11, 12]. Extracts from algal species including Chlorella, Saragassum, Laminaria, Durvillaea, Ascophyllum, and Ecklonia have biostimulant effects on strawberry and other agriculture crops. Algal extracts also contain secondary metabolites that have antifungal properties and have the ability to control various crop fungal diseases [13]. The extract of Spirulina platensis has the ability to increase the biomass of the reddish plant. Its extract contains bio-stimulants that increase plant growth [14]. Several cyanobacteria and algae have the capability to fix different forms of nitrogen and thus increase the fertility of the environment for plant growth. They can decrease the demand for nitrogen fertilizers by $25 \%$. Several algae produce biocidal agents that include benzoic acid and majusculonic acid. These compounds are toxic to different 
nematodes, fungi and other harmful species that attack plants. Algae perform $50 \%$ of the world's photosynthesis, therefore, playing a major role in carbon dioxide sequestration and oxygen production [15-17]. Due to fast growth and enormous biomass production, algae are favorable sources of bioenergy $[18,19]$. Ulva extracts can help in germination and increases root size in Arabidopsis. Ulva extract contains hormones and biostimulants for plant growth, which help to increase biomass [20]. In the present work, we have investigated the chemical composition of methanolic extract from the freshwater macroalgae Chara vulgaris, Cladophora glomerata, and Spirogyra crassa, that prevail in the river Swat and Kabul. Using gas chromatography-mass spectrometry (GCMS), this work analyzes the availability of different fatty acids (saturated and un-saturated) and other phytochemical components in essential oils of methanolic extract. Furthermore, the bioactivities of the methanolic extracts of these selected freshwater green macroalgae are examined, to explore their possible medicinal properties.

\section{Materials and methods}

The freshwater macroalgae, Chara vulgaris, Cladophora glomerata and Spirogyra crassa were collected from the river Swat and river Kabul flowing through the Charsadda district, KPK state of Pakistan (Fig. 1). Taxonomic identification of the macroalgae was carried out by Prof. Arshad Iqbal of the Botany Department, Islamia College University Peshawar with the help of Prescot., [21], Tiffany and Britton books [22]. A specimen of each macroalgae has been stored in the Herbarium of the Botany department, Islamia College University Peshawar, Pakistan.

\section{Sample collection and extraction}

The collected freshwater macroalgae were washed with tap water and then with distilled water to remove sand, mud and other weeds. The clean freshwater macroalgae plants were spread out on plain paper and shade dried at room temperature for about 10 days and then ground into fine powder using a mechanical grinder. This powder was dipped in methanol for 3-4 days with irregular mixing with a glass rod for extraction of secondary metabolites. The mixture was filtered to remove any solid particles. This filtrate was concentrated by removing the methanol through rotary evaporator. This procedure was repeated three times for full extraction from the macroalgae powder. A dark green colored thick slurry was obtained after complete elimination of methanol under reduced pressure using a rotary evaporator. The obtained extract was stored in a refrigerator until further use.

\section{Gas chromatography-mass spectrometry (GC-MS) analyses}

GC-MS analyses of the essential oils present in the $\mathrm{n}$-hexane fraction of the three freshwater macroalgae was carried out on a GC-MS-QP2010 Plus, comprising an AOC-20i auto sampler and gas chromatograph interfaced to a mass spectrometer instrument employing the following conditions. A column elite- 1 fused silica capillary column (30 M length $\times 0.25 \mathrm{~mm}$-inner diameter $\times 1 \mu \mathrm{M}$

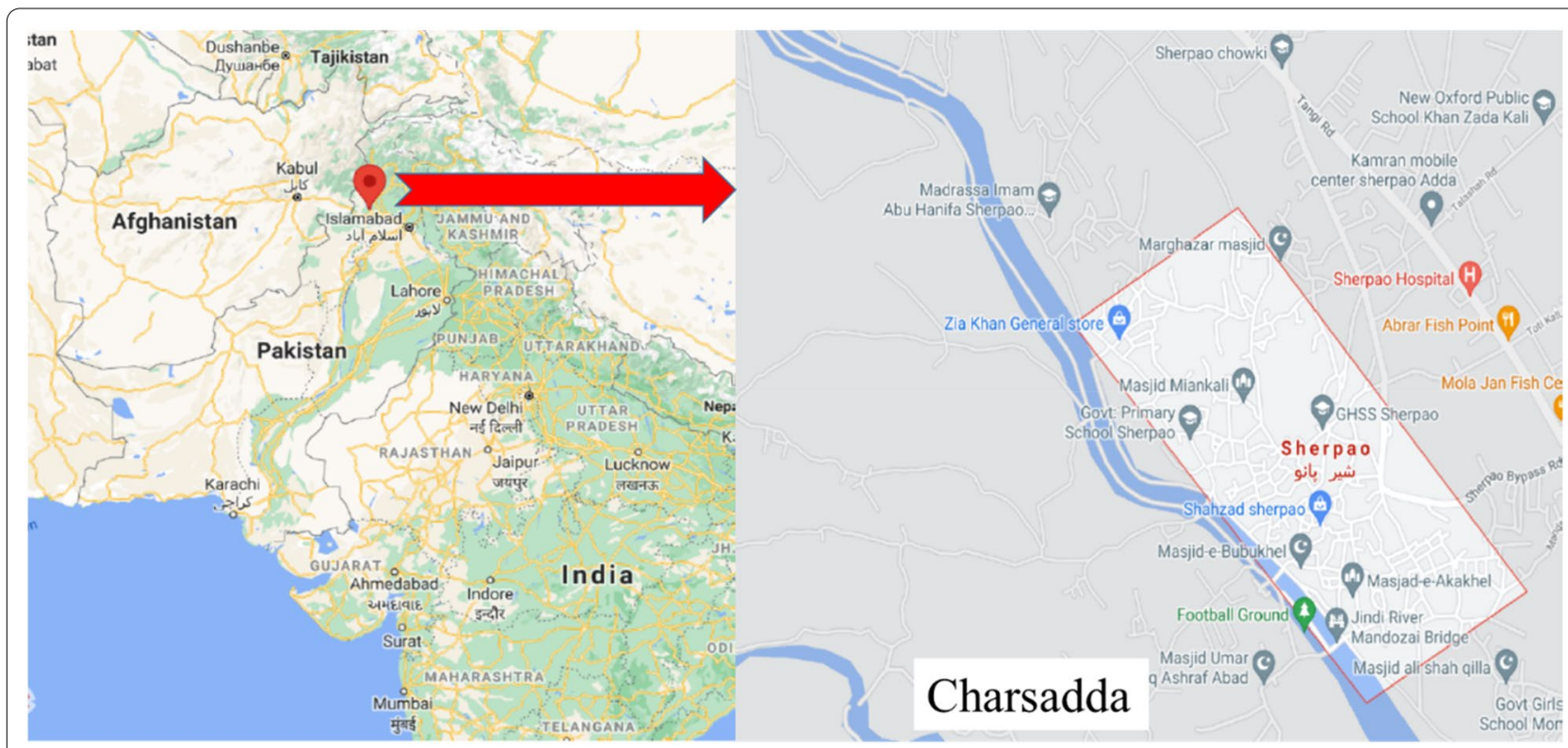

Fig. 1 Map of the area from which the macroalgae were collected and used in this study 
film thickness, composed of $100 \%$ dimethyl polysiloxane) was operated in electron impact mode at $70 \mathrm{eV}$. Helium gas $(99.99 \%)$ was used as a carrier gas at a constant flow of $1 \mathrm{~mL} / \mathrm{min}$ and an injection volume of $0.5 \mu \mathrm{L}$ was employed (split ratio of 10:1), with an injector temperature of $250{ }^{\circ} \mathrm{C}$ and an ion-source temperature of $280{ }^{\circ} \mathrm{C}$. The oven temperature was programmed from $110{ }^{\circ} \mathrm{C}$ (isothermal for $2 \mathrm{~min}$ ), with an increase of $10{ }^{\circ} \mathrm{C} /$ min to $200{ }^{\circ} \mathrm{C}$, then at $5{ }^{\circ} \mathrm{C} /$ min to $280{ }^{\circ} \mathrm{C}$, ending with a 9 min isothermal period at $280^{\circ} \mathrm{C}$. Each mass spectrum was collected at $70 \mathrm{eV}$ with a scan interval of $0.5 \mathrm{~s}$ and fragments from 50 to $450 \mathrm{Da}$. Total GC running time was $46.95 \mathrm{~min}$. The relative percentage amount of each component was calculated by comparing its average peak area to the total areas. The software used to handle the mass spectra and chromatograms was TurboMass Version 2.0.7.

\section{Antibacterial activity}

The methanolic extracts of the freshwater macroalgae were tested for antibacterial activity using the disk diffusion method [23]. Extract antibacterial action was tested against four different bacteria. These were Gram-positive Staphylococcus aureus, Bacillus subtilis and Gram-negative Xanthomonas campestris, Ralastonia solanacearum. Each tested bacterium was transferred aseptically with an inoculating loop to a test tube having $5 \mathrm{~mL}$ of sterilized deionized water. Enough inoculum was poured so that the turbidity equaled standards. The test tube suspension $(1 \mathrm{~mL})$ was added to $15 \mathrm{~mL}$ of nutrient agar before setting aside the seeded agar plate $(9 \mathrm{~cm}$ in diameter) to solidify for $15 \mathrm{~min}$. Three disks of Whatman's No. 1 filter paper, $6 \mathrm{~mm}$ in diameter, were used to test the antimicrobial activity. Three concentrations of 500; 1000 and $1500 \mathrm{ppm}$ were made for the extracts and were added to each respective disk (the three disks were equidistance from one another). For a negative control, dimethyl sulfoxide (DMSO) was added to one of the control disks and augmentin was used as a positive control on the other disk. All the discs were left for evaporation in sterile conditions and when the discs were dry, they were placed on sterile agar petri dishes freshly inoculated with the tested bacterial cell suspension. The Petri dishes were incubated for $24 \mathrm{~h}$ at a temperature of $36{ }^{\circ} \mathrm{C}$ in an aerobic environment. After the incubation time period, confluent bacterial growth was monitored. The zone of inhibition was measured in $\mathrm{mm}$ [24].

\section{Phytotoxicity assay}

The methanolic extracts of the freshwater macroalgae were tested for their herbicidal action. Lemna minor plant was used as a testing subject [1]. A series of solutions were made from the methanolic extracts by dissolving in methanol $(\mathrm{MeOH})$. They had concentrations of 100, 300 and $500 \mathrm{ppm}$. Then each was transferred to a glass plate and the solvent was allowed to evaporate overnight. The sterilized media $(100 \mathrm{~mL})$ was poured on the glass containing dried extract and 10 rosettes of Lemna minor, each containing three fronds, were placed on it. A negative control as well as a positive control (atrazine) was run in parallel under a constant supply of tungsten light at room temperature for 7 days. The growth of Lemna minor was determined by counting the number of effected fronds (appearance of yellow color). The phytotoxicity was recorded by contrast with the negative control [25].

\section{Insecticidal assay}

The methanolic extracts of the freshwater macroalgae were tested for their insecticidal activity against Tribolium castaneum (a common grain pest known as red flour beetle). Test samples were prepared by dissolving $20 \mathrm{mg}$ of extract in $20 \mathrm{ml}$ of d. $\mathrm{H}_{2} \mathrm{O}$ to create a stock solution. The sample $\left(1572.7 \mu \mathrm{g} / \mathrm{cm}^{2}\right)$ was loaded over filter paper of an appropriate size $(9 \mathrm{~cm})$ on Petri dish plates using a micropipette. The plates were left for $24 \mathrm{~h}$ to evaporate the solvent. A negative control was treated with solvent to determine the effect of the solvent. Another batch, supplemented with reference insecticide was also made. The next morning, 10 healthy and active insects of each species of the same size and age were added to each plate including control (methanol) and standard drug (dichlorovos as a standard insecticide of $393.17 \mu \mathrm{g} / \mathrm{cm}^{2}$ ). Thereafter the plates were incubated in a growth chamber at $27{ }^{\circ} \mathrm{C}$ for $24 \mathrm{~h}$ with $50 \%$ relative humidity. All of them were kept without food for $24 \mathrm{~h}$. Mortality counts were carried out after a $24 \mathrm{~h}$ exposure period [26]. For calculation, the number of surviving insects was counted and the mortality (\%) was determined. Results were the mean of three different experiments.

\section{Cytotoxicity assay}

A cytotoxic bioassay was performed to screen for those bioactive compounds that inhibit cell functions [7]. The lethality of the extract was checked against brine shrimp larvae using the procedure described by Oley and coworkers [27, 28]. Brine shrimp napuli were hatched in brine ( $35 \%$ aqueous sea salt solution). 31 day hatched napuli were then added to vials containing different concentrations of the extract (100, 300 and $500 \mathrm{ppm})$ in $15 \mathrm{~mL}$ brine with $1 \%$ DMSO. The DMSO was used to increase the solubility of the extract in brine. Three replicates were used for each concentration; blank $(15 \mathrm{~mL}$ brine with $1 \%$ DMSO) was also run as a negative control. 


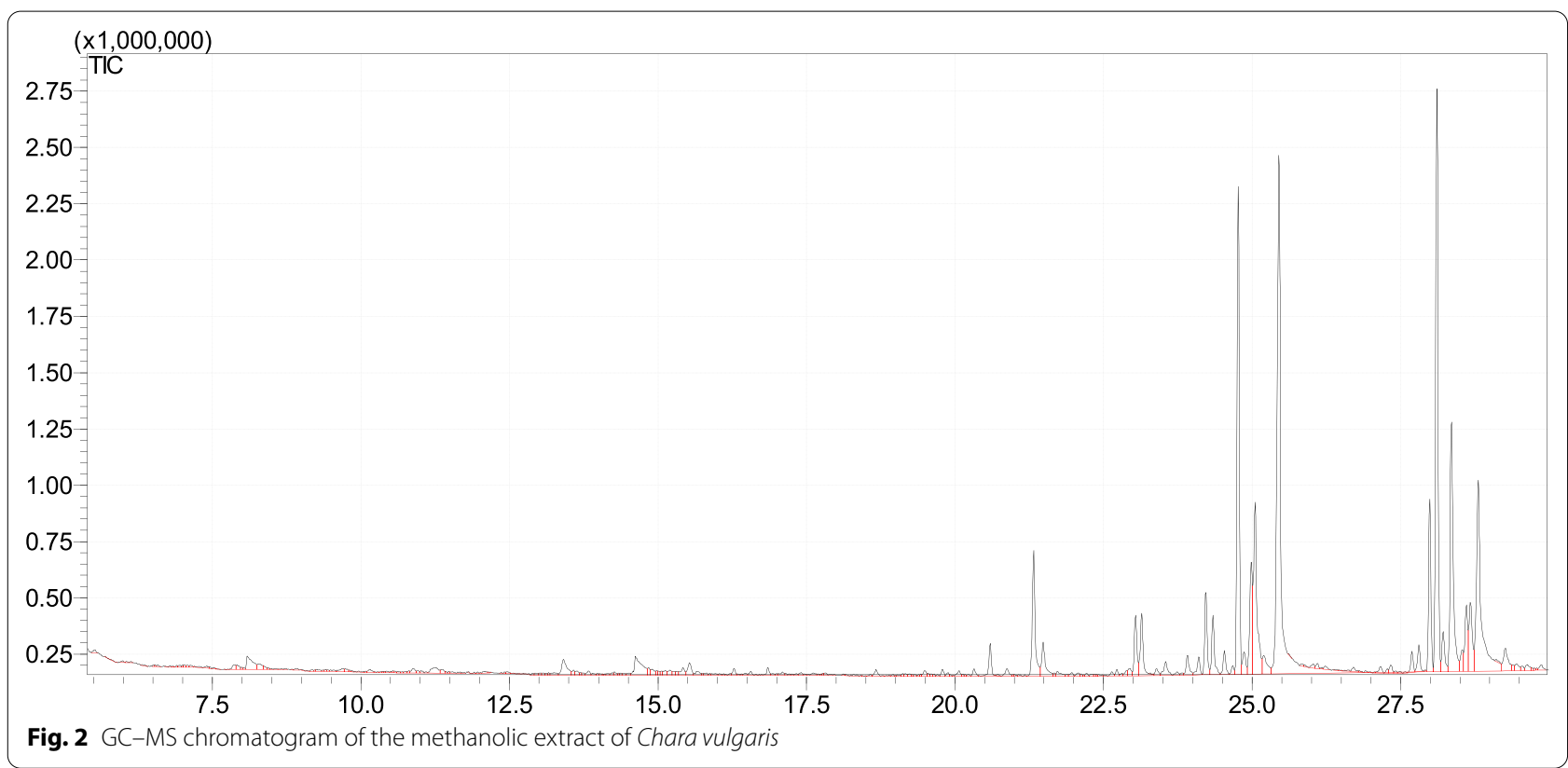

The toxicity of each sample was compared with that of blank (brine solution without crude extract) [28].

\section{Statistical analysis}

All the experiments were performed in triplicate and standard deviations (SD) were calculated in MS Office Excel. The results are presented as mean value with $\pm \mathrm{SD}$.

\section{Results and discussion}

\section{Gas chromatography-mass spectrometry (GC-MS)}

Figure 2 shows the GC-MS chromatogram of the methanolic extract of Chara vulgaris. A number of chemical compounds can be observed at different retention times in the chromatogram. These includes 3,5-dihydroxy6-methyl-2,3-dihydro-4H-Pyran-4-one; (S)-(+)-2', $3^{\prime}$ Dideoxyribonolactone at around $7.5 \mathrm{~min}$ of retention time. 1-Nitro-2-octanone is present at a retention time of $11 \mathrm{~min}$. A peak for Biofermin is observed at $14 \mathrm{~min}$ and then a large peak of phenylpropanolamine is present at $14.5 \mathrm{~min}$. Alpha-limonene diepoxide; tetradecanoic acid; p-menthane-1,2,8,9-diepoxy; 4-acetoxyphenyl-3-morpholino-propan-1-one; n-hexadecanoic acid; dl-Phenylephrine peak is present at retention time of $24.5 \mathrm{~min}$. Phenylephrine has many properties that includes as a decongestant in winter, and it is also used for mydriasis (pupil dilation). It is also used to enhance blood pressure, and to treat hemorrhoids. Hexahydropseudoionone (terpene ketone), which is a fragrant in perfumes and cosmetics, was also detected. The 1-docosene; octadecanoic acid and various types of esters were also present as represented by different peaks at the end of the chromatogram of methanolic extract of Chrara vulgaris (Fig. 2 and Table 1). These results show the presence of various terpenes, ketones, alkenes, amines, complex fatty acids and their methyl esters in the methanolic extract of Chara vulgaris.

Figure 3 and Table 2 show the GC-MS profile of the various phytochemicals present in the methanolic extract of Cladophora glomerata. There are several methyl esters of complex fatty acids, such as 9-hexadecanoic acid, 5-octadecanoic acid and their derivatives. Similarly, 9,12,15-Octadecatrienoic acid, (Z,Z,Z)- and other related octadecatrienoic acids were observed in the chromatogram of the methanolic extract of $C$. glomerata. 3-Propanediol,2-hydroxymethyl-2-nitro; Uranone,5,6,7,7-tetrahydro-4,4,7 a-trimethy, (R)-; Z,Z,Z1,4,6,9-Nonadecatetraene and other related alkenes are observed at various retention times in the GC-MS analysis of the methanolic extract of C. glomerata. Most of the compounds mentioned in Table 2 and detected in other fractions of $C$. glomerata have commercial value and that is why it is a good source of revenue if it is grown on a commercial scale [29]. The C. glomerata extract is rich in phenolics that have high antioxidant activity [30], with the capability to reduce oxidative stress in mitochondria [31]. Similar compounds have been reported from Cladophora extract through GC-MS and were observed to have antifungal properties [32]. It has also been observed that when these extract are combined with nanoparticles their antifungal activity enhances [33].

The GC-MS chromatogram of Spirogyra crassa showed methyl esters of different complex fatty acids, 
Table 1 Quantitative GC-MS analysis of methanolic extract of Chara vulgaris

\begin{tabular}{|c|c|c|c|c|}
\hline ID\# & Name of compound & R. time (min) & Area & Conc. (\%) \\
\hline 1 & Propylene carbonate & 13.412 & 70,990 & 1.21 \\
\hline 2 & Benzene methanol, alpha-(1-aminoethyl)-[R-( $\left.\left.R^{*}, R^{*}\right)\right]$ - & 14.620 & $3,72,196$ & 6.32 \\
\hline 3 & Methyl tetradecanoate & 25.591 & 87,808 & 1.49 \\
\hline 4 & 5-Isopropyl-6-methyl-hepta-3,5-dien-2-ol & 21.485 & 92,257 & 1.57 \\
\hline 5 & 1-Octadecyne & 23.039 & 67,429 & 1.15 \\
\hline 6 & Hexahydropseudoionone & 23.142 & $1,48,738$ & 2.53 \\
\hline 7 & Pentadecanoic acid & 23.393 & 10,539 & 0.18 \\
\hline 8 & (2E)-3,7,11,15-Tetramethyl-2hexadecen-1-ol & 23.912 & 26,673 & 0.45 \\
\hline 9 & Linolenic acid, methyl ester & 24.103 & 22,935 & 0.39 \\
\hline 10 & Methyl(7E,10E,13E)-7,10,13-hexadecatrienoate & 24.221 & $1,11,973$ & 1.90 \\
\hline 11 & 11-Octadecenoic acid, methyl ester & 24.342 & 10,478 & 0.13 \\
\hline 12 & Methyl 9-cycloprophylnonanoate & 24.532 & 41,508 & 0.71 \\
\hline 13 & Hexadecanoic acid, methyl ester & 24.766 & $12,46,193$ & 21.17 \\
\hline 14 & 1,4,8-Cyclododecatriene & 24.985 & $2,24,533$ & 3.81 \\
\hline 15 & 9-Hexadecanoic acid & 25.050 & $2,79,819$ & 4.75 \\
\hline 16 & $n$-Hexadecanoic acid & 25.453 & $10,24,948$ & 17.41 \\
\hline 17 & $(9 \mathrm{E}, 12 \mathrm{E}, 15 \mathrm{E})-9,12,,15-O c t a d e c a t r i e n-1-\mathrm{ol}$ & 27.159 & 7988 & 0.14 \\
\hline 18 & Caprylic ether & 27.337 & 19,441 & 0.33 \\
\hline 19 & Linolenic acid, methyl ester & 27.692 & 19,979 & 0.34 \\
\hline 20 & Methyl(Z)-5,11,14,17-eicosatetraenoate & 27.809 & 33,018 & 0.56 \\
\hline 21 & 9,12-Octadecadienoic acid, methyl ester, (E,E)- & 27.991 & $2,07,419$ & 3.52 \\
\hline 22 & 9,12-Octadecadienoyl chloride, (Z,Z)- & 28.111 & $5,68,327$ & 9.65 \\
\hline 23 & 10-Octadecynoic acid, methyl ester & 28.215 & 47,501 & 0.81 \\
\hline 24 & Phytol & 28.355 & $4,62,143$ & 7.85 \\
\hline 25 & Octadecynoic acid, methyl ester & 28.605 & $1,44,147$ & 2.45 \\
\hline 26 & 9,12-Octadecadienoic acid, methyl ester, (E,E)- & 28.674 & $1,29,180$ & 2.19 \\
\hline 27 & 9,12,15-Octadecatrienoic acid, (Z,Z,Z)- & 28.808 & $3,12,003$ & 5.30 \\
\hline 28 & Octadecanoic acid & 29.261 & 29,697 & 0.50 \\
\hline
\end{tabular}

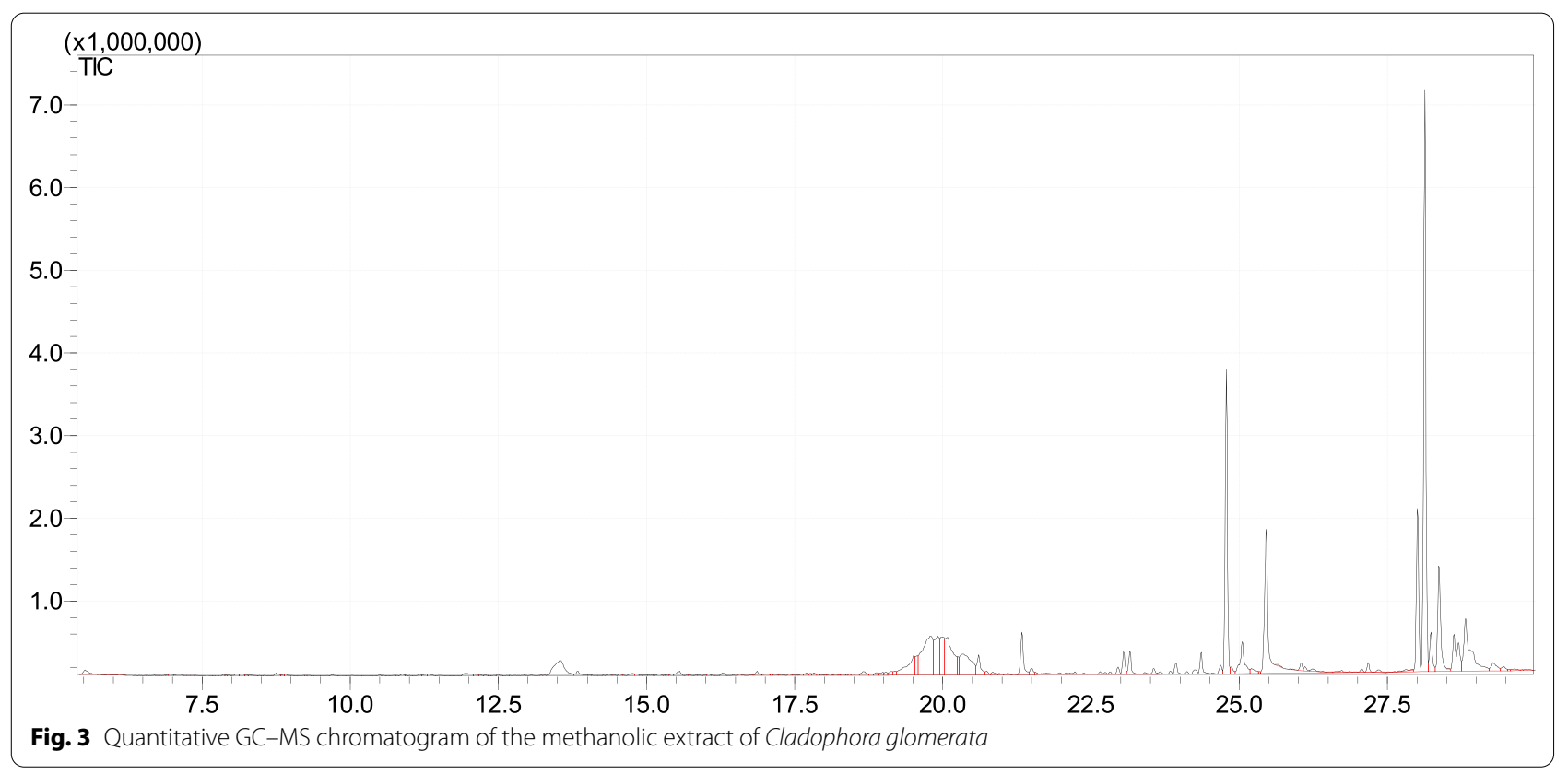


Table 2 Quantitative GC-MS analysis of methanolic extract of Cladophora glomerata

\begin{tabular}{|c|c|c|c|c|}
\hline ID\# & Name of compound & R. time & Area & Conc. (\%) \\
\hline 1 & 1,3-Propanediol,2-(hydroxymethyl)-2-nitro- & 13.548 & $4,37,710$ & 5.62 \\
\hline 2 & 2(4H)-Benzofuranose,5,6,7,7a-tetrahydro-4,4,7a-trimethyl-, (R)- & 16.285 & 12,367 & 0.16 \\
\hline 3 & Dodecanoic acid & 16.863 & 15,169 & 0.19 \\
\hline 4 & Methyl tetradecanonate & 20.603 & $1,01,327$ & 1.30 \\
\hline 5 & Tetradecanoic acid & 21.335 & $1,76,076$ & 2.26 \\
\hline 6 & 1-Octadecyne & 23.052 & 68,907 & 0.89 \\
\hline 7 & 2-Undecanone,6,10-dimethyl- & 23.156 & $1,53,684$ & 1.97 \\
\hline 8 & 1-Octadecyne & 23.557 & 20,549 & 0.26 \\
\hline 9 & 3,7,11,15-Tetramethyl-2-hexadecen-1-ol & 23.927 & 29,928 & 0.38 \\
\hline 10 & 9-Hexadecenoic acid, methyl ester, (Z)- & 24.358 & 72,482 & 0.93 \\
\hline 11 & 5-Octadecenoic acid, methyl ester & 24.687 & 24,843 & 0.32 \\
\hline 12 & Hexadecenoic acid, methyl ester & 24.532 & 41,508 & 0.71 \\
\hline 13 & Hexadecanoic acid, methyl ester & 24.783 & $21,11,096$ & 27.12 \\
\hline 14 & $n$-Hexadecanoic acid & 25.456 & $7,42,555$ & 9.54 \\
\hline 15 & $Z, Z, Z-1,4,6,9-$ Nonadecatetraene & 27.071 & 9939 & 0.13 \\
\hline 16 & 1,4,8-Dodecatriene, $(\mathrm{E}, \mathrm{E}, \mathrm{E})$ - & 27.178 & 36,437 & 0.47 \\
\hline 17 & 9,12-Octadecadienoic acid, methyl ester (E,E)- & 28.010 & $5,17,411$ & 6.65 \\
\hline 18 & 9-Octadecanoic acid & 28.134 & $16,47,973$ & 21.17 \\
\hline 19 & 10-Octadecanoic acid, methyl ester & 28.234 & $1,42,577$ & 1.83 \\
\hline 20 & Phytol & 28.370 & $5,73,746$ & 7.37 \\
\hline 21 & Octadecanoic acid, methyl ester & 28.623 & $2,60,251$ & 3.34 \\
\hline 22 & 9,12-Octadecadienoic acid, methyl ester (E,E)- & 28.698 & $1,43,532$ & 1.84 \\
\hline 23 & 9,12,15-Octadecatrienoic acid, (Z,Z,Z)- & 28.819 & $3,11,027$ & 4.00 \\
\hline
\end{tabular}

such as decanoic acid; hexa and octa-decenoic acids and their various types (Fig. 4; Table 3). Like other GC-MS of macroalgae, phytol was also present in it. 1-Octadecyne is also present in Spirogyra extract.

\section{Biological activities of the methanolic extracts}

The methanolic extracts of the freshwater macroalgae were tested for biological activity by four different methods.

\section{Antibacterial activity}

The methanolic extracts of three freshwater green macroalgal species-Chara vulgaris, Cladophora glomerata and Spirogyra crassa-were tested against two Grampositive and two Gram-negative species of bacteria. The methanolic extracts of all three species showed strong to moderate antibacterial activity against all four tested bacterial organisms (Table 4 ). The $C$. vulgaris methanolic extract showed weak activity against $B$. subtilis. The $C$. glomerata and $S$. crassa extracts showed moderate antibacterial action against $B$. subtilis as comapred to the standard drug augmentin. All three macroalgae extracts showed weak antibacterial activity against Styphylococus aureus at three different concentrations as compared to the standard antibiotic augmentin. When extracts were tested against the Gram-negative bacteria, Xanthomonas compestris, they showed weak activity as compared to the standard drug augmentin. All three macroalgae methanolic extracts showed moderate antibacterial action against the Gram-negative bacteria, Ralastonia solanacerum. Thus, these extracts showed weak antimicrobial activities. Several other investigators showed similar bactericidal activities from the extract of these and related macroalgal species. The methanolic extract of Chara vulgaris and its ethanolicsoluble part were active against a variety of Grampositive and Gram-negative bacteria [34]. The aqueous extract of Chara globularisis was reported to show antibacterial activity against a natural population of bacteria from pond water [35]. The sterols extracted from Chara wallichii exhibited bioactivity against several species of bacteria [36]. This indicates that freshwater green algae may also display antibacterial activity, and consistently all of them are weakly active in our work (Table 4). The methanolic extract of C. glomerata has moderate antibacterial activity against the multidrug resistant Acinetobacter baumannii and several other pathogens [37]. The extract from C. glomerata also have antibacterial action against both Gram-positive and 


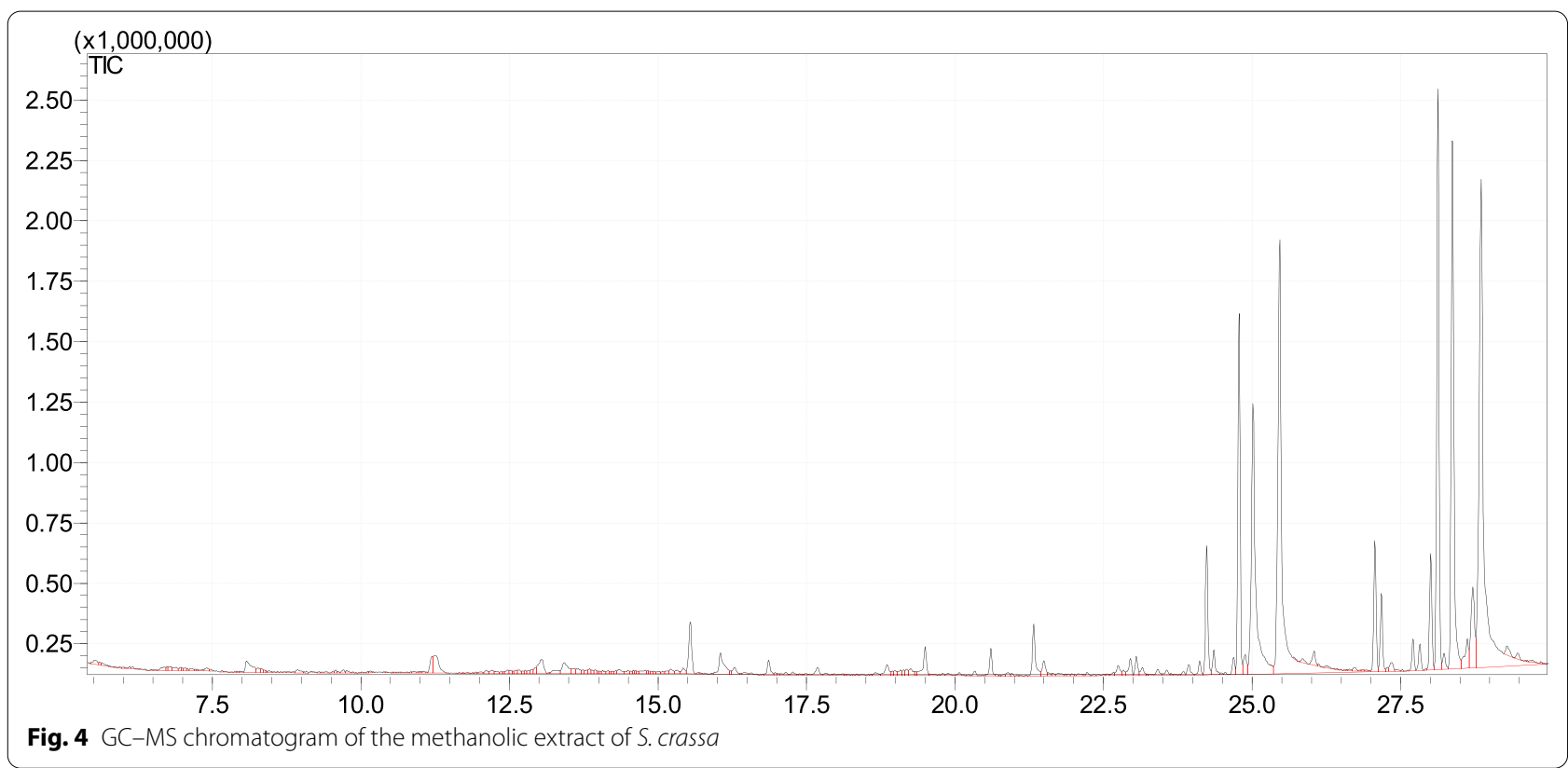

Table 3 Quantitative GC-MS analysis of methanolic extract of Spirogyra crassa

\begin{tabular}{|c|c|c|c|c|}
\hline ID\# & Name of compound & R. time & Area & Conc. (\%) \\
\hline 1 & Tridecanoic acid, methyl ester & 16.045 & 37,156 & 0.81 \\
\hline 2 & Undecanoic acid & 16.861 & 18,084 & 0.40 \\
\hline 3 & Methyl tetradecanoate & 20.603 & 65,548 & 1.43 \\
\hline 4 & 7-Oxabicyclo[4.1.0]heptane,1-methyl-4-(2-methyloxiranyl)- & 21.496 & 29,890 & 0.65 \\
\hline 5 & Decanoic acid, methyl ester & 22.737 & 13,925 & 0.30 \\
\hline 6 & 1-Octadecyne & 23.053 & 21,791 & 0.48 \\
\hline 7 & 2-Undecanone,6,10-dimethyl- & 23.155 & 14,643 & 0.32 \\
\hline 8 & 3,7,11,15-Tetramethyl-2-hexadecen-1-ol & 24.118 & 10,503 & 0.23 \\
\hline 9 & 7,10-Hexadecadienoic acid, methyl ester & 24.117 & 15,866 & 0.35 \\
\hline 10 & 9-Hexadecenoic acid, methyl ester, (Z)- & 24.357 & 26,471 & 0.58 \\
\hline 11 & 6-Octadecenoic acid, methyl ester(Z)- & 24.689 & 15,734 & 0.34 \\
\hline 12 & Hexadecenoic acid, methyl ester & 24.780 & $8,73,551$ & 19.12 \\
\hline 13 & $n$-Hexadecanoic acid & 25.465 & $8,24,789$ & 18.06 \\
\hline 14 & 9,12,15-Octadecatrien-1-ol, (Z,Z,Z)- & 27.067 & $1,50,748$ & 3.30 \\
\hline 15 & 1-Pentanol,3-methyl-2propyl- & 27.348 & 13,159 & 0.29 \\
\hline 16 & 9,12,15-Octadecatrienoic acid, methyl ester, (Z,Z,Z)- & 28.129 & $5,11,251$ & 11.19 \\
\hline 17 & Phytol & 28.371 & $9,57,524$ & 20.96 \\
\hline 18 & 9,12-Octadecadienoic acid, methyl ester (E,E)- & 28.715 & $1,45,788$ & 3.19 \\
\hline 19 & Cis,cis,cis-7,10,13-Hexadecatrienal & 28.860 & $8,21,435$ & 17.98 \\
\hline
\end{tabular}

negative strains [38]. The $C$. glomerata extract also posses bactericidal potential against Mycobacterium species [39].

\section{Insecticidal activity}

All of the three algal extracts were tested for their insecticiadal activity against the insect pest Tribolium castaneum, and dichlorovos was used as a standard insecticide. Chara vulgaris showed weak insecticidal activity, while Cladophora glomerata and Spirogyra 
Table 4 Antimicrobial activity of methanolic extract of Chara vulgaris, Cladophora glomerata and Spirogyra crassa

\begin{tabular}{|c|c|c|c|c|c|c|}
\hline \multicolumn{4}{|c|}{ Bacillus subtilis ( $G+v e)$} & \multicolumn{3}{|c|}{ Staphylococcus aureus (G + ve) } \\
\hline \multirow[t]{2}{*}{ Sample } & \multicolumn{3}{|c|}{ Concentration (ppm) } & \multicolumn{3}{|c|}{ Concentration (ppm) } \\
\hline & 500 & 1000 & 1500 & 500 & 1000 & 1500 \\
\hline C.vulgaris & 0 & $11.73 \pm 0.25$ & $13.17 \pm 0.76$ & $10.4 \pm 0.2$ & $12.1 \pm 0.36$ & $15.93 \pm 0.21$ \\
\hline C. glomerata & $17.33 \pm 0.15$ & $19.03 \pm 0.31$ & $22.17 \pm 0.21$ & 0 & $10.33 \pm 0.15$ & $13.97 \pm 0.57$ \\
\hline S. crassa & $15.17 \pm 0.21$ & $17.17 \pm 0.35$ & $23.17 \pm 0.31$ & $10.1 \pm 0.1$ & $11.77 \pm 0.21$ & $14.97 \pm 0.15$ \\
\hline Augmentin & $32.07 \pm 0.21$ & $32.93 \pm 0.57$ & $33.17 \pm$ & $29.33 \pm 0.70$ & $32.83 \pm 0.21$ & $32.87 \pm 0.23$ \\
\hline \multicolumn{4}{|c|}{ Xanthomonas compestris (G - ve) } & \multicolumn{3}{|c|}{ Ralastonia solanacerum (G - ve) } \\
\hline & \multicolumn{3}{|c|}{ Concentration (ppm) } & \multicolumn{3}{|c|}{ Concentration (ppm) } \\
\hline & 500 & 1000 & 1500 & 500 & 1000 & 1500 \\
\hline C.vulgaris & - & $10.83 \pm 0.76$ & $13.17 \pm 0.76$ & - & $11.17 \pm 0.29$ & $11.5 \pm 0.5$ \\
\hline C. glomerata & $17.2 \pm 0.2$ & $20.1 \pm 0.2$ & $24.87 \pm 0.25$ & - & $11.73 \pm 0.38$ & $13.57 \pm 0.51$ \\
\hline S. crassa & $13.23 \pm 0.15$ & $17.3 \pm 0.4$ & $21 \pm 0.4$ & $10.1 \pm 0.1$ & $12.37 \pm 0.42$ & $11.17 \pm 0.58$ \\
\hline Augmentin/+ C & $33.1 \pm 0.1$ & $33.03 \pm 0.30$ & $33.1 \pm 0.1$ & $30.07 \pm 0.21$ & $30.83 \pm 0.91$ & $33.17 \pm 0.21$ \\
\hline
\end{tabular}

The values show the zone of inhibition in millimeters, as detailed in the materials and methods. Augmentin was used as a standard drug, while DMSO was used as a negative control

Table 5 Insecticidal activity of crude methanolic extract of selected freshwater green macroalgae

\begin{tabular}{llll}
\hline Sample & $\mathbf{5 0 0} \mathbf{p p m}$ & $\mathbf{1 0 0 0} \mathbf{p p m}$ & $\mathbf{1 5 0 0} \mathbf{~ p p m}$ \\
\hline C. vulgaris & $2.33 \pm 0.60$ & $5.33 \pm 1.53$ & $5.33 \pm 1.53$ \\
C. glomerata & $5.33 \pm 0.60$ & $6.33 \pm 0.58$ & $6.33 \pm 0.58$ \\
S. crassa & $5.00 \pm 1.00$ & $6.66 \pm 1.53$ & $6.66 \pm 1.53$ \\
Dichlorovos & 7 & 10 & 10 \\
\hline
\end{tabular}

crassa showed moderate to high insecticidal potential at 500, 1000 and 1500 ppm concentration (Table 5). Thus, C. glomerata and S. crassa contained compounds that are toxic to pests that destroy wheat and other grains. In the past, several algal extract studies showed insecticidal properties, for example Chara globularis has been reported to contain compounds with insecticidal properties [40]. The C. glomerata extract also possesses antiparasitic properties and is active against human vaginal parasites [41]. The phenolic extract of Chara vulgaris has more insecticidal potential than the standard drug albendazole against larva (Cysticercus) of Taenia taeniaeformis in rats [42]. Ethanolic extract of $C$. vulgaris has low insecticidal activity against the cotton leafworm Spodoptera littoralis, while C. glomerata has moderate activity [43].

\section{Phytotoxic activity}

The methanol extracts obtained from three species of freshwater green macroalgae were tested against Lemna spp. for phytotoxic activity. The Spirogyra crassa showed
Table 6 Phytotoxic activity of freshwater macroalgae methanolic extract on Lemna minor

\begin{tabular}{lccl}
\hline Sample & \multicolumn{3}{l}{ Concentration $(\mathbf{p p m})$} \\
\cline { 2 - 4 } & $\mathbf{1 0 0}$ & $\mathbf{3 0 0}$ & $\mathbf{5 0 0}$ \\
\hline C. vulgaris & $2.33 \pm 0.58$ & $3.33 \pm 0.58$ & $2.67 \pm 1.15$ \\
C. glomerata & $3.67 \pm 0.58$ & $3.67 \pm 0.58$ & $5.67 \pm 1.15$ \\
S. crassa & $6.33 \pm 1.53$ & $6.33 \pm 1.53$ & $6.33 \pm 0.58$ \\
Atrazine (herbicides) & $5 \pm 1$ & $7.33 \pm 0.58$ & $8.33 \pm 0.58$ \\
Control (water) & $1.67 \pm 0.58$ & $0.33 \pm 0.58$ & $0.33 \pm 0.58$ \\
\hline
\end{tabular}

almost equal phytotoxic activity, such as the standard drug atrazine at all three concentrations tested (Table 6). C. glomerata extract also showed moderate phytotoxic activity at 100, 300 and 500 ppm. While the Chara vulgaris extract has poor phytotoxic activity. Most of the investigated algal species showed more than 50\% phytotoxic activity against $L$. minor, with only Cladophora glomerata showing lesser activity (50\%). Previous work has also shown that the methanol and ethanol extracts along with isolated sterols of Chara wallichii also exhibited significant phytotoxic activity against L. minor [36]. These results suggest that crude methanolic extracts need to be further evaluated for purified compounds that have powerful phytotoxic action.

\section{Cytotoxic bioassay}

Possible cytotoxic effects of the methanolic extracts of the three freshwater macroalgae were investigated against brine shrimp larvae. All three investigated extracts 
Table 7 Cytotoxic activity of methanolic extract of selected freshwater macroalgae on brine shrimp

\begin{tabular}{llll}
\hline Sample & \multicolumn{3}{l}{ Concentration $(\mathbf{p p m})$} \\
\cline { 2 - 4 } & $\mathbf{1 0 0}$ & $\mathbf{3 0 0}$ & $\mathbf{5 0 0}$ \\
\hline C. vulgaris & $13.33 \pm 1.25$ & $16.33 \pm 1.25$ & $17.5 \pm 0.5$ \\
C. glomerata & $14 \pm 2.16$ & $15.33 \pm 1.69$ & $18 \pm 0.82$ \\
S. crassa & $13.67 \pm 1.25$ & $16 \pm 1.63$ & $16.67 \pm 0.47$ \\
DMSO & 0.0 & 0.0 & 0.0 \\
\hline
\end{tabular}

displayed non-significant cytotoxic activity against brine shrimp (Table 7). Macroalgae contain several compounds that can be toxic to other cells and can inhibit the function of cells. Cytokinins-known to be ubiquitous among higher plants-have been isolated from Chara globularis [44]. Abscisic acid (ABA) has been detected in C. foetida [45], and sterols present in C. coralline were found to exhibit cytotoxic activity [34]. These observations indicate that freshwater green macroalgae may possess some cytotoxic substances. The methanolic extract was also tested for cytotoixc activity against human breast cancer cell lines and it was observed that it has no inhibitory action against cancer in this context [46]. However, when silver nanoparticles containing Cladophora extract are made they have suitable cytotoxic properties against colon cancers [47]. The C. golmerata was shown to be non-cytotoxic in in vivo studies [48].

\section{Conclusions}

GC-MS investigation of methanolic extract of the freshwater macroalgae Chara vulgaris, Cladophora glomerata and Spirogyra crassa from the Swat and Kabul rivers revealed that there are a number of different valuable compounds present in them. These compounds have medicinal, nutraceutical, cosmeceutical, and agricultural importance. Although our results showed weak bactericidal and cytotoxic activities, they have phytotoxic and insecticidal properties, suggesting that several compounds present in these methanolic extracts can be used in the agricultural sector. Therefore, these macroalgae may be part of the development of traditional medicines, nutraceuticals and food in the agricultural industry. The different compounds can be used as pesticides and insecticides. The biomass can be utilized for biofuel purposes. Further investigation is needed to isolate novel active compounds from these and other freshwater macroalgae from the Charsadda district, which may help in the development of algal farms on river banks.

\section{Acknowledgements}

We are thankful to the Higher Education Commission of Pakistan for their financial support to conduct this research study.

\section{Authors' contributions}

ZS performed the experiments with SB under the supervision of Al. The initial manuscript was written by $\mathrm{ZS}, \mathrm{Al}$ and $\mathrm{SB}$ and $\mathrm{MJ}$ refined it and provided valuable comments. A-HE helped in interpretation of GC-MS analyses. All authors read and approved the final manuscript.

\section{Funding}

Higher Education Commission of Pakistan SRGP Grant.

Availability of data and materials

Available upon request.

\section{Declarations}

Ethics approval and consent to participate

Not applicable.

Consent for publication

Not applicable.

\section{Competing interests}

All the authors declare that they have no competing interests.

\section{Author details}

'Department of Botany, Islamia College University Peshawar, Peshawar 25120, Pakistan. ${ }^{2}$ Department of Chemistry, Islamia College University Peshawar, Peshawar 25120, Pakistan. ${ }^{3}$ Department of Biotechnology, University of Science and Technology Bannu, Bannu 28100, Pakistan. ${ }^{4}$ Core Labs, King Abdullah University of Science and Technology (KAUST), Thuwal 23955-6900, Saudi Arabia. ${ }^{5}$ Division of Biological and Environmental Sciences and Engineering (BESE), King Abdullah University of Science and Technology (KAUST), Thuwal 23955-6900, Saudi Arabia.

Received: 17 July 2021 Accepted: 14 November 2021

Published online: 15 January 2022

References

1. Round FE. The ecology of algae. Cambridge: Cambridge University Press; 1984.

2. Champa P, Whangchai N, Jaturonglumlert S, Nakao N, Whangchai $\mathrm{K}$, Technology F, et al. Determination of phytochemical compound from Spirogyra sp. using ultrasonic assisted extraction. Int J GEOMATE. 2016;11:2391-6.

3. Dwaish AS, Yousif DYM, Alwan AH, Lefta N. Anti-dermatophytes activity of macroalgal extracts (Chara vulgaris) isolated from Baghdad City-Iraq. J Glob Pharma Technol. 2018. https://doi.org/10.5958/0974-360X.2018. 00993.9.

4. Wood L. Algae products market by type, application, source, form, and region—global forecast to 2023. Renew Sustain Energy Rev. 2018. https://doi.org/10.1016/..rser.2017.08.075.

5. Gullón B, Gagaoua M, Barba FJ, Gullón P, Zhang W, Lorenzo JM. Seaweeds as promising resource of bioactive compounds: overview of novel extraction strategies and design of tailored meat products. Trends Food Sci Technol. 2020;100:1-18.

6. Pulz MO, Gross W. Valuable products from biotechnology of microalgae. Appl Microbiol Biotechnol. 2004. https://doi.org/10.1007/ s00253-004-1647-x.

7. Shamsabadi FT, Khoddami A, Shamsabadi FT. Comparison of tamoxifen with edible seaweed (Eucheuma cottonii L.) extract in suppressing breast tumor comparison of tamoxifen with edible seaweed (Eucheuma cottonii L.) extract in suppressing breast tumor. Nutr Cancer. 2013. https://doi.org/ 10.1080/01635581.2013.756528.

8. Zbakh H, Chiheb H, Bouziane H, Sánchez VM, Riadi H. Antibacterial activity of benthic marine algae extracts from the Mediterranean Coast of Morocco. J Microbiol Biotechnol Food Sci. 2020;10:219-28.

9. Wu Z, Li S, Li J, Chen Y, Saurav K, Zhang Q, et al. Antibacterial and cytotoxic new napyradiomycins from the marine-derived Streptomyces sp. SCSIO 10428. Mar Drugs. 2013. https://doi.org/10.3390/md11062113. 
10. Munir M, Qureshi R, Bibi M, Khan AM. Pharmaceutical aptitude of Cladophora: a comprehensive review. Algal Res. 2019. https://doi.org/10.1016/j. algal.2019.101476.

11. Pan S, Jeevanandam J, Danquah MK. Benefits of algal extracts in sustainable agriculture. Gd Challenges Biol Biotechnol. 2019. https://doi.org/10.1007/ 978-3-030-25233-5_14.

12. Chojnacka K. Innovative bio-products for agriculture. Open Chem. 2015;13:932-7.

13. Righini $H$, Roberti $R$, Baraldi E. Use of algae in strawberry management. J Appl Phycol. 2018;30:3551-64.

14. Godlewska K, Michalak I, Pacyga P, Baśladyńska S, Chojnacka K. Potential applications of cyanobacteria: Spirulina platensis filtrates and homogenates in agriculture. World J Microbiol Biotechnol. 2019. https://doi.org/10.1007/ s11274-019-2653-6.

15. Renuka N, Guldhe A, Prasanna R, Singh P, Bux F. Microalgae as multifunctional options in modern agriculture: current trends, prospects and challenges. Biotechnol Adv. 2018;36:1255-73.

16. Badshah SL, Sun J, Mula S, Gorka M, Baker P, Luthra R, et al. Mutations in algal and cyanobacterial Photosystem I that independently affect the yield of initial charge separation in the two electron transfer cofactor branches. Biochim Biophys Acta Bioenerg. 2017;1859:42-55.

17. Badshah SL, Mabkhot Y, Al-Showiman SS. Photosynthesis at the far-red region of the spectrum in Acaryochloris marina. Biol Res. 2017. https://doi. org/10.1186/s40659-017-0120-0.

18. Badshah SL, Shah Z, Alves JLF, da Silva JCG, Noreen N, lqbal A. Kinetic and thermodynamics study of the pyrolytic process of the freshwater macroalga, Chara vulgaris. J Appl Phycol. 2021. https://doi.org/10.1007/ s10811-021-02459-3.

19. Badshah SL, Shah Z, Francisco-Alves JL, da Silva GJC, Iqbal A. Pyrolysis of the freshwater macroalgae Spirogyra crassa: evaluating its bioenergy potential using kinetic triplet and thermodynamic parameters. Renew Energy. 2021;179:1169-78

20. Ghaderiardakani F, Collas E, Damiano DK, Tagg K, Graham NS, Coates JC. Effects of green seaweed extract on Arabidopsis early development suggest roles for hormone signalling in plant responses to algal fertilisers. Sci Rep. 2019. https://doi.org/10.1038/s41598-018-38093-2.

21. Prescott GW. Algae of the Western great lakes area: exclusive of desmids and diatoms. Bloomfield Hills: Cranbrook Institute of Science; 1951.

22. Tiffany LH, Britton ME, et al. Algae of illinois. New York: Hafner; 1971.

23. Sasidharan S, Darah I, Noordin MKMJ. Screening antimicrobial activity of various extracts of Gracilaria changii. Pharm Biol. 2009;47:72-6.

24. Qayyum S, Basharat S, Mian AH, Qayum S, Ali M, Changsheng P, Shahzad M, Sultan F. Isolation, identification and antibacterial study of pigmented bacteria. Appl Nanosci. 2020;10:4495-503.

25. Nisar M, Qayum M, Shah MR, Siddiqui HL, Kaleem WA, Zia-UI-Haq M. Biological screening of impatiens bicolor Royle. Pak J Bot. 2010;42:1903-7.

26. Farhana K. Screening of insecticides by impregnation method on storage pests. Man Bioassay Tech. 2000. https://doi.org/10.3791/2129.

27. Mary JS, Vinotha P, Pradeep AM. Screening for in vitro cytotoxic activity of seaweed, Sargassum sp. against Hep-2 and MCF-7 cancer cell lines. Asian Pac J Cancer Prev. 2012;13:6073-6.

28. Sarah QS, Anny FC, Misbahuddin M. Brine shrimp lethality assay. Bangladesh J Pharmacol. 2017:12:186-9.

29. Michalak I, Messyasz B. Concise review of Cladophora spp.: macroalgae of commercial interest. J Appl Phycol. 2021:33:133-66.

30. Korzeniowska K, Łęska B, Wieczorek PP. Isolation and determination of phenolic compounds from freshwater Cladophora glomerata. Algal Res. 2020. https://doi.org/10.1016/j.algal.2020.101912.

31. Bourebaba L, Michalak I, Röcken M, Marycz K. Cladophora glomerata methanolic extract decreases oxidative stress and improves viability and mitochondrial potential in equine adipose derived mesenchymal stem cells (ASCs). Biomed Pharmacother. 2019;111:6-18.

32. Mohammed DY, Dwaish AS, Jawad ALM. Anti-phytopathogenic fungi activities of Cladophora glomerata extract. World J Pharm Res. 2013;2:1868-77.

33. Abdulwahid KE, Dwaish AS, Dakhil OA. Green synthesis and characterization of zinc oxide nanoparticles from Cladophora glomerata and its antifungal activity against some fungal isolates. Plant Arch. 2019;19:3527-32.

34. Khaliq-uz-Zaman SM, Simin S, Mustafa S, Leghari SM, Ahmad VU, et al. Bioactive compounds in Chara corallina var. wallichii (A. BR.) RD Wood (Charophyta). Pak J Bot. 1998;30:19-31.
35. Anthoni U, Nielsen PH, Smith-Hansen L, Wium-Andersen S, Christophersen C. Charamin, a quaternary ammonium ion antibiotic from the green alga Chara globularis. J Org Chem. 1987;52:694-5.

36. Zaman SMK, Simin K, Shameel M. Antimicrobial activity and phytotoxicity of sterols from Chara wallichii A. Br. (Charophyta). Pak J Sci Ind Res. 2001;44:301-4.

37. Yuvaraj N, Kanmani P, Satishkumar R, Paari KA, Pattukumar V, Arul V. Extraction, purification and partial characterization of Cladophora glomerata against multidrug resistant human pathogen Acinetobacter baumannii and fish pathogens. World J Fish Mar Sci. 2011;3:51-7.

38. Soltani S, Saadatmand S, Khavarinejad R, Nejadsattari T. Antioxidant and antibacterial activities of Cladophora glomerata (L.) Kütz. in Caspian Sea Coast, Iran. Afr J Biotechnol. 2011;10:7684-9.

39. Orhan I, Şener B, Atici T, Palittapongarnpim P. In vitro antimycobacterial potential of some fresh-water macroalgae and aqueous plants. Pharm Biol. 2002:40:568-9.

40. Jacobsen N, Pedersen L-EK. Synthesis and insecticidal properties of derivatives of propane-1,3-dithiol (analogues of the insecticidal derivatives of dithiolane and trithiane from the alga Chara globularis Thuillier). Pestic Sci. 1983;14:90-7.

41. Abbas SK, Lafta SN, Majeed HA. Study the effect of Cladophora glomerata algae extract on the Trichomonas vaginalis parasite. J Pharm Sci Res. 2019;11:519-22

42. Al-Sultan EY, Abdullah BH, Al-Waeli AA. The effect of Phenolic extract of the green alga Chara vulgaris on the Cysticercus of Taenia taeniaeformis. Iraqi J Aquac. 2017;14:129-40.

43. Saber AA, Hamed SM, Abdel-Rahim EFM, Cantonati M. Insecticidal prospects of algal and cyanobacterial extracts against the cotton leafworm Spodoptera littoralis. Vie Milieu. 2018:68:199-212.

44. Zhang W, Yamane H, Takahashi N, Chapman DJ, Phinney BO. Identification of a cytokinin in the green alga Chara globularis. Phytochemistry. 1989;28:337-8.

45. Tietz A, Ruttkowski U, Kohler R, KasprikW. Further investigations on the occurrence and the effects of abscisic acid in algae. Biochem Physiol Pflanzr. 1989;184:259-66.

46. Al-Jaber GT, Al-Ismaeel WN, Al-Ali AL. The effect of Rhus coriaria L. methanolic extract on cytotoxicity of Cladophora glomerata L. Kützing methanolic extract against human breast carcinoma MCF-7 cell line. Int J Pharm Res. 2021. https://doi.org/10.31838/ijpr/2021.13.02.008

47. Acharya D, Satapathy S, Thathapudi JJ, Somu P, Mishra G. Biogenic synthesis of silver nanoparticles using marine algae Cladophora glomerata and evaluation of apoptotic effects in human colon cancer cells. Mater Technol. 2020. https://doi.org/10.1080/10667857.2020.1863597.

48. Amornlerdpison D, Mengumphan K, Thumvijit S, Peerapornpisal Y. Antioxidant and anti-inflammatory activities of freshwater macroalga, Cladophoro glomerata Kützing. Thai J Agric Sci. 2011;44:283-91.

\section{Publisher's Note}

Springer Nature remains neutral with regard to jurisdictional claims in published maps and institutional affiliations.

\section{Submit your manuscript to a SpringerOpen ${ }^{\circ}$ journal and benefit from:}

- Convenient online submission

- Rigorous peer review

- Open access: articles freely available online

- High visibility within the field

Retaining the copyright to your article

Submit your next manuscript at springeropen.com 